\title{
HVMANITAS
}

\section{Língua, identidade e convivência étnica nas Histórias de Heródoto}

Autor(es): Silva, Maria de Fátima

Publicado por: Faculdade de Letras da Universidade de Coimbra, Instituto de Estudos

URL

persistente:

DOI: $\quad$ DOI:http://dx.doi.org/10.14195/2183-1718_61_4

Accessed : $\quad$ 26-Apr-2023 12:46:14

A navegação consulta e descarregamento dos títulos inseridos nas Bibliotecas Digitais UC Digitalis, UC Pombalina e UC Impactum, pressupõem a aceitação plena e sem reservas dos Termos e Condições de Uso destas Bibliotecas Digitais, disponíveis em https://digitalis.uc.pt/pt-pt/termos.

Conforme exposto nos referidos Termos e Condições de Uso, o descarregamento de títulos de acesso restrito requer uma licença válida de autorização devendo o utilizador aceder ao(s) documento(s) a partir de um endereço de IP da instituição detentora da supramencionada licença.

Ao utilizador é apenas permitido o descarregamento para uso pessoal, pelo que o emprego do(s) título(s) descarregado(s) para outro fim, designadamente comercial, carece de autorização do respetivo autor ou editor da obra.

Na medida em que todas as obras da UC Digitalis se encontram protegidas pelo Código do Direito de Autor e Direitos Conexos e demais legislação aplicável, toda a cópia, parcial ou total, deste documento, nos casos em que é legalmente admitida, deverá conter ou fazer-se acompanhar por este aviso.

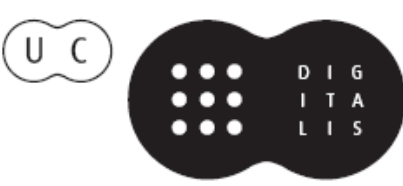


humanitas

\section{Vol. LXI}

IMPRENSA DA UNIVERSIDADE DE COIMBRA

COIMBRA UNIVERSITY PRESS 


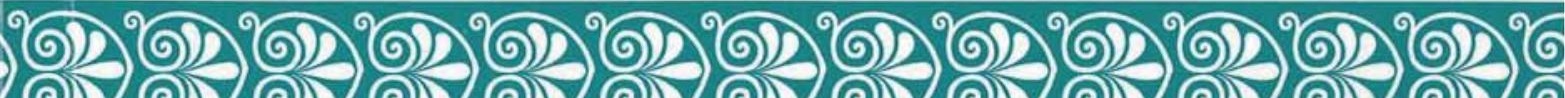

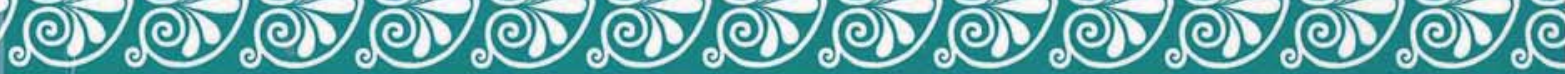

Vol. LXI 


\title{
LÍNGUA, IDENTIDADE E CONVIVÊNCIA ÉTNICA NAS HISTÓRIAS DE HERÓDOTO
}

\author{
Maria de Fátima Silva \\ Universidade de Coimbra \\ fanp@ci.uc.pt
}

\begin{abstract}
Resumo
Heródoto é um testemunho relevante de todo um processo de progressiva adaptação linguística entre Gregos e Bárbaros. Em muitas ocasiões, o historiador de Halicarnasso regista uma sequência que vai da total incomunicabilidade, pelo recurso à linguagem gestual, até ao multilinguismo.

Palavras-chave: bárbaros, comunicação linguística, linguagem e desenvolvimento.

Abstract

Herodotus testifies the process of a linguistic adaptation between Greeks and Barbarians. He often underlines a sequence of attitudes beginning with a complete incommunicability, progressing by the use of a gestual language, until a true multilinguism.
\end{abstract}

Keywords: barbarians, verbal communication, language and progress.

Num momento histórico em que, por razões políticas e militares, os contactos entre Gregos e Bárbaros ganharam uma relevância primordial, um factor de identidade cultural tão forte como a língua, condição para as noções de individualidade e de convivência entre povos, teve uma centralidade evidente. Como cronista deste tremendo conflito - as guerras pérsicas, que envolveram a Ásia e a Europa, no séc. V a. C. - Heródoto é também um testemunho relevante da consciência nacional e da imposição de con- 
tactos exteriores que a sua época experimentou. A diferença linguística serviu ora para estabelecer fronteiras políticas, ora como elemento de coesão cultural. Para além da dicotomia radical entre Gregos e Bárbaros, a língua fixou também limites a espaços mais pequenos, os das comunidades em que cada um desses grandes blocos se subdividia. Dentro de cada comunidade, a par da religião e dos costumes, o código linguístico estimula um sentimento de coesão. É paradigmático o apelo à identidade grega, lançado em plena fase de resistência ao invasor bárbaro por uma voz ateniense (8. 144. 2): o que une os Gregos e faz deles uma família humana e política é, antes de mais, "a comunidade de sangue e de língua", a par dos santuários, cultos, costumes e instituições idênticos ${ }^{1}$. Pode, por isso, servir, para definir "inimigos ou adversários", ou também, por um exercício de aprendizagem difícil e longo, para cimentar novas parcerias. Ou seja, partindo de um sentimento de estranheza, a que, desde logo, o termo "bárbaro" deu expressão, o mundo grego antigo ensaiava um esforço de compreensão e tolerância perante a diferença. Fomentado, por um lado por essa mesma abertura cultural, por outro pela necessidade prática de comunicação, o plurilinguismo foi-se tornando uma realidade. Como grego da Ásia, originário de um espaço de charneira entre os dois campos em litígio, para além de viajante curioso e interessado, Heródoto é também, nesta perspectiva, um testemunho insubstituível. Nas referências que faz aos "intérpretes", que lhe facilitaram o acesso ao quotidiano do mundo conhecido de então, ou ao ensaiar, ele mesmo, equivalências vocabulares ou etimologias, para esclarecer, diante de um público grego, novidades que povoavam uma vasta realidade extra-fronteiras, o historiador de Halicarnasso documentava o que foram os primeiros esforços por uma compreensão linguística / tradução entre comunidades humanas.

Uma primeira posição pode servir de ponto de partida a todo este processo de aproximação gradual, a chamada "teoria pelásgica", talvez criada por Hecateu (FGrHist 1F 119) e que Heródoto assume com clareza, "segundo a qual a Grécia pré-helénica se chamava Pelásgia e era habitada por uma população autóctone, os Pelasgos" (1. 56. 2, 2. 56. 1, 8. 44. 2)2; entre eles contavam-se as comunidades que reivindicavam autoctonia

${ }^{1}$ Vide Soares, C. L. (2003), "A língua, um instrumento de diálogo cultural em Heródoto", Biblos n. s. 1: 13-22.

${ }^{2}$ Asheri, D. (21989), Erodoto, Le Storie. I. La Lidia e la Persia. Milano: Mondadori Editore, 299. 
(Arcádios, Tessálios e Atenienses, por exemplo) e deles se excluíam os Dórios, segundo Heródoto "de origem helénica", que respondiam à permanência tradicional do primeiro grupo com uma enorme mobilidade (1. 56. 2). Do ponto de vista que nos interessa, o da língua, a helenização ocorreu, segundo esta teoria, quando a divergência étnica foi diluída pela imposição, por parte do invasor dórico, da sua língua, o grego, aos povos autóctones, os Pelasgos utilizadores de uma língua bárbara (1. 57. 2) 3 $^{3}$. Apesar de esta visão não ter o aplauso da moderna investigação ${ }^{4}$, aponta num sentido importante: o do sentimento que a Grécia, arcaica e clássica ${ }^{5}$, alimentava de que a uniformização linguística estava na base da sua própria identidade cultural (1. 57-58). Mas é também interessante que Heródoto inclua, na sua exposição, a ideia de que a esta generalização não foram estranhos uns focos de resistência que, em época histórica, persistiam como ilhas isoladas no mapa linguístico geral (1. 57. 3): "Eis porque nem os Crestoniatas nem os habitantes de Placia falam uma língua idêntica a qualquer das comunidades que hoje em dia os rodeiam, enquanto entre si partilham uma comunidade linguística - o que prova que preservam o idioma que trouxeram, quando da migração para esse território". Independentemente de toda a controvérsia gerada por esta afirmação, que não nos cabe aqui analisar, é interessante sublinhar como Heródoto deixa patente, nestes casos de excepção, a questão do ascendente e de uma espécie

${ }^{3}$ A polémica questão sobre a identidade dos Pelasgos põe em dúvida este pormenor sobre a natureza "bárbara" da língua que falavam. O próprio

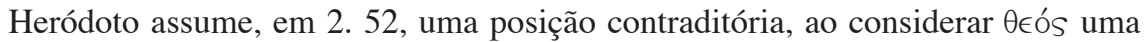

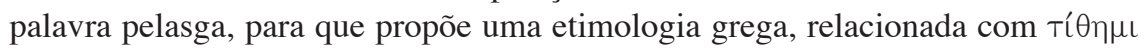
"pôr, estabelecer, salvaguardar". How, W. W. and Wells, J. (reimpr. 1991), A commentary on Herodotus, I (I-IV). Oxford: University Press, 444 salienta como Tucídides parece flutuar também sobre uma tendencial confusão entre os Pelasgos como os habitantes primitivos da Grécia (Th. 1. 3), ou um povo de bárbaros seu contemporâneo, residente no Helesponto (Th. 4. 109).

${ }^{4}$ Myres, J. L. (1907), "A history of Pelasgian theory", JHS 27: 195-196; How and Wells 1991: 442-446; Ferreira, J. R. (1983), Hélade e Helenos. Génese e evolução de um conceito. Coimbra: Universidade de Coimbra 283-284.

${ }^{5}$ Vide Asheri ${ }^{2}$ 1989: 299, a propósito de expressões homéricas como "Argos pelásgica" (a Tessália), Il. 2. 681, "Zeus pelasgo" (de Dodona), Il. 16. 233, ou de poetas e autores de genealogias que inventaram o epónimo "pelasgo". A teoria aqui defendida por Heródoto teve uma grande divulgação nos séc. V e IV a. C. (cf. Éforo, FGrHist 70F 113, 119, 142; Strab. 5. 2. 4, 220-221, 7. 7. 10, 327-328, 9. $2.3,401)$. 
de preservação de identidade que faz com que comunidades específicas salvaguardem uma língua relacionada com a sua origem e, através dela, mantenham um certo isolamento territorial. Esta circunstância, pontualmente registada em território grego, convive com aquela outra, de coesão e permanência, que Heródoto enuncia em 1. 58. 1: "Quanto à raça helénica, desde que surgiu utilizou sempre o mesmo idioma". Esta é uma característica que deveria reger as relações entre Gregos e dirimir conflitos armados, já que o uso de uma só língua facilitaria a resolução diplomática, "através de arautos e mensageiros", das possíveis divergências (7. 9. $2 \beta$ ). Sob este ponto de vista, Heródoto reconhece na língua um factor político determinante ${ }^{6}$.

Apesar da uniformidade linguística que reconhece entre todos os Gregos, a época clássica acentua também as diferenças dialectais que caracterizam o particularismo linguístico de certas comunidades. Ao definir o mundo iónico como um xadrez étnico, político e religioso, Heródoto distingue a língua como um factor poderoso no estabelecimento de diferenças. Destaca então quatro variantes dialectais na Iónia, que designa com

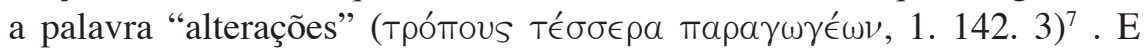

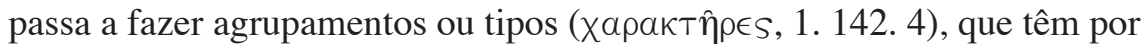
base um critério geográfico: Mileto, Miunte e Priene, todas situadas na Cária, "falam do mesmo modo", ou seja, "usam o mesmo dialecto" (кат̀̀

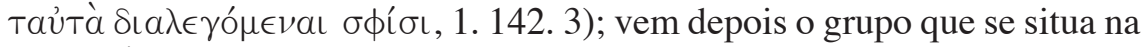
Lídia (Éfeso, Cólofon, Lébedo, Teos, Clazómenas e Foceia), “cuja língua não tem nenhuma afinidade ${ }^{8}$ com as anteriores" (

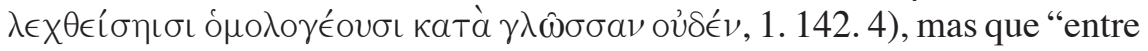

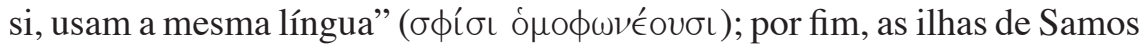
e Quios, e Eritreia, no continente, repartem-se da forma seguinte: Quios e Eritreia, situadas frente a frente, falam o mesmo dialecto (ката тüvті̀

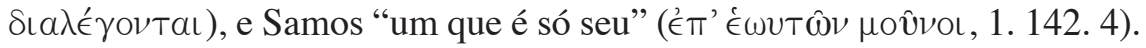

${ }^{6}$ Embora seja o persa Mardónio o porta-voz desta receita para as divergências entre Gregos, é fácil conjecturar que o princípio em si seria o que o próprio historiador pretende defender; cf. Legrand, P. E. (1951), Hérodote. Histoires VII. Paris: Les Belles Lettres 20 n. 1.

${ }^{7}$ Asheri ${ }^{2}$ 1989: 348 interroga-se sobre qual o padrão que Heródoto tem em mente, como representando o "puro iónico": será o literário, ou seja, o "homérico"? Em "alterações" entrevê um sabor depreciativo.

${ }^{8}$ Heródoto parece radicalizar as diferenças, como se houvesse uma distância notável, mais do que fonética talvez também semântica. 
A diferenciação geográfica implica a ideia de um cruzamento com outras línguas locais, de origem oriental, como o cário ou o lídio.

Estabelecida a coesão que faz dos Gregos uma comunidade linguística, apesar das variantes menores que possa comportar, está aberto o caminho para a noção da diferença ou oposição que os separa, no mesmo plano, de todo um mundo extra-fronteiras, de língua distinta e, à partida, incompreensível, a que se aplicou, por tradição, a designação onomatopeica de "bárbara"9. Nela vai incluído também um sentimento de repulsa e inimizade, que tem expressão no modo de identificar o grande adversário oriental, o império persa com toda a sua mistura étnica, como "a gente que fala

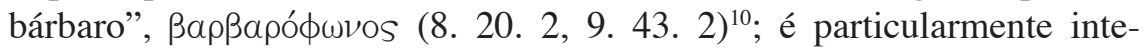
ressante o facto de esta dupla ocorrência do termo se incluir na transcrição de oráculos, uma linguagem destinada a um público indiferenciado de ouvintes, o que talvez sugira a sua vulgaridade; por outro lado, em 9. 43. 2, integra uma oposição entre Gregos e um inimigo que apenas se identifica

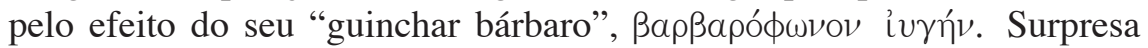
semelhante é a que Heródoto assinala entre Gregos e Egípcios, quando estes últimos se confrontaram com uma primeira imigração de Gregos no seu território e simultaneamente com um primeiro contacto com falantes de outra língua. Heródoto usa aqui, para a sensação causada pelos Gregos, um termo que parece acentuar apenas a diferença, isenta de um juízo de

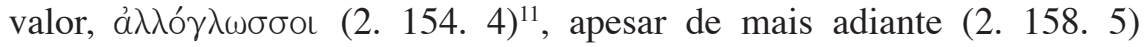
reconhecer que o epíteto que os Egípcios aplicavam a quem não falava a

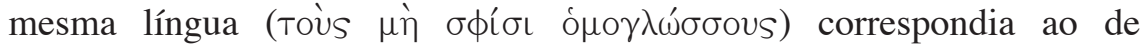

${ }^{9}$ Hall, E. (1989), Inventing the barbarian. Greek self-definition through tragedy. Oxford: Clarendon Press 4, salienta que "a prioridade do critério linguístico na afirmação da etnicidade grega” resulta da própria dispersão geográfica.

${ }^{10}$ Esta palavra ocorre já em $I l$. 2. 867, aplicada aos Cários como os que têm uma língua estranha; mais tarde, Estrabão (663) aplica-a também a quem conhece mal o grego. Não tem, antes do séc. V, um sentido abrangente para todo um universo que não fala grego; cf. Hall 1989: 9-11. Importa sublinhar a este propósito a distinção que Heródoto faz entre $\phi \omega \nu \eta ́$, aplicada aos "sons", e $\gamma \lambda \omega \sigma \sigma \sigma \alpha$, como uma "língua" verdadeiramente estruturada.

${ }^{11}$ Schrader, C. (1992), Heródoto. História I-II. Madrid: Gredos 450 n. 553, informa de que a palavra era usada, no plano administrativo, para designar os mercenários estrangeiros, gregos e outros, por oposição aos egípcios; refere, como testemunho, uma inscrição encontrada no templo de Abu Simbel, de 589 a. C., que a aplica aos soldados gregos que Psamético II enviou para a Núbia (cf. 2. 161.1). 
"bárbaros"12, atestando, do lado egípcio, um sentimento de superioridade cultural.

Em consequência da noção de diferença linguística, que vem acompanhada de um sentimento generalizado de orgulho da comunidade que avalia em relação às outras, Heródoto integra no seu relato (2. 2) uma história conhecida ${ }^{13}$, que procura determinar o povo mais antigo à face da terra através de um critério linguístico. Após uma experiência feita por Psamético I (664-610 a. C.), os Egípcios tiveram de abdicar, segundo esta versão, do que julgavam uma prerrogativa sua, em favor dos Frígios, a quem tiveram de ceder a primazia em antiguidade (2. 2. 1). Desde logo é significativo que seja o critério linguístico o aplicado na avaliação da antiguidade e consequente prestígio; como é também muito sugestivo o princípio que orienta a experiência, o da redução de dois recém-nascidos à condição de criaturas meramente "fisiológicas", isoladas do nomos social (cf. 2. 15. 2-3). Foi esse o sentido do isolamento a que foram sujeitos, num monte, longe do convívio humano e em contacto apenas com os rebanhos. Passados dois anos, vencido o período em que aos sons inarticulados se substituiu a linguagem propriamente dita, verificou-se que a primeira palavra que as crianças pronunciaram ( $\dot{\phi} \phi \dot{\omega} \nu \in \mathrm{O} \nu)$, diante do pastor que lhes descerrava a porta do cativeiro, foi $\beta \in \kappa o ́ s$, que passaram a repetir nas suas visitas posteriores. Feita uma investigação, Psamético apurou que a palavra se usava em frígio para designar o "pão". Independentemente de as ins-

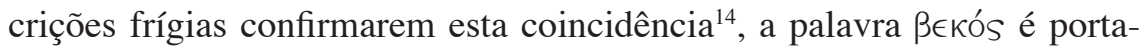

${ }^{12}$ Schrader 1992: 454 n. 569, esclarece que Heródoto, naturalmente, não quer dizer que "bárbaros", uma palavra indo-europeia, fosse usada pelos Egípcios, mas algo equivalente. Na "tradução" produzida por Heródoto, julgo defensável a ideia de uma certa depreciação que, em geral, os Egípcios nutriam pelos estrangeiros, defendendo, por oposição, a superioridade da sua língua e cultura.

${ }^{13}$ Trata-se de uma ficção; cf. Ar. Nu. 398 e schol. ad loc., $\beta \in \kappa \kappa \in \sigma \in ́ \lambda \eta \nu \in$ como epíteto de Cronos, usado pela comédia como paradigma de um tempo remoto. Sobre o assunto, vide Taillardat, J. (1965), Les images d"Aristophane. Paris: Les Belles Lettres 262; Dover, K. J. (reimpr. 1976), Aristophanes. Clouds. Oxford: University Press 109. Lloyd, A. B. and Fraschetti, A. ( $\left.{ }^{3} 1996\right)$, Erodoto, Le Storie. II. L'Egitto. Milano: Mondadori Editore 234, lembram que a mesma história, que consideram uma invenção iónica, aparecia também em Hecateu. Por outro lado, era crença generalizada entre os Gregos que os Egípcios eram o povo mais antigo do mundo; cf. Hdt. 2. 15. 3; Arist. Pol. 1329b; D. S. 1. 101.

14 Cf. Friedrich, J. (1932), Kleinasiatische Sprachdenkmaler. Berlin, 133, 140; Hippon. fr. 75 Diehl sobre a existência da mesma palavra, com igual 
dora de uma sonoridade onomatopaica, que tem a ver com a proximidade em que as crianças estiveram em relação ao gado. Assim, não apenas fica implícito o aprendizado de uma língua "materna" pela simples repetição, como também a associação entre o som e um objecto ou propósito, o alimento básico neste caso, que surge como uma manifestação animal espontânea.

A mesma sugestão de que a linguagem humana parece ter, com a dos animais, uma afinidade visível, o que se torna patente quando o elemento racional, que procede à interpretação, não actua por se encontrar perante um código desconhecido, resulta das metáforas vulgarmente usadas para uma língua incompreensível ou "bárbara". Esta é uma evidência na narrativa que Heródoto faz da fundação do oráculo de Zeus em Dodona. Porque os oráculos tendem a ser lugares cosmopolitas, pelo cruzamento de diferentes utilizadores que proporcionam ${ }^{15}$, Heródoto relata que a fundadora do célebre oráculo de Dodona foi uma egípcia, sacerdotisa de Ámon, raptada por Fenícios e levada para a Grécia (2. 54. 1) ${ }^{16}$. Assim racionaliza a história mítica, oficial no santuário, de que, vinda do Egipto, lá chegou uma pomba negra ${ }^{17}$. Com voz humana, ela ordenou que ali fosse instituído um oráculo de Zeus. Mas Heródoto vai mais longe e imagina que, depois de ter reconstituído, no seu lugar de exílio, um culto equivalente ao que exercia na sua terra, a egípcia, "quando aprendeu a língua grega", lá fundou

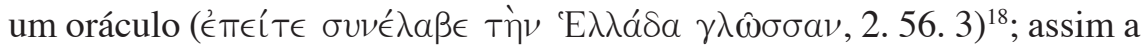
comunicação linguística, a partir da língua local, aparece como condição de uma nova fase na existência do oráculo, que se seguiu a uma primitiva em que seria o som emitido pela folhagem de um carvalho sagrado ou das pombas que a ele se abrigavam entendido como a emissão da voz do deus (cf. S. Tr. 171-172). Para compatibilizar as duas versões, a que racionalmente

significado, usada também em Chipre.

${ }^{15}$ Cf. o plurilinguismo da Pítia, em Delfos, documentado por Heródoto em 4. 155. 2-3.

${ }^{16}$ Esta, aliás, é uma versão errada, porque o oráculo de Dodona, muito antigo na Grécia (III milénio a. C.), tinha proveniência indo-europeia; vide Lloyd and Fraschetti ${ }^{3}$ 1996: 276.

${ }^{17}$ Em homenagem a esta tradição, a pomba era venerada em Dodona como ave sagrada de Zeus e o nome de "pombas" dado às sacerdotisas em exercício.

${ }^{18}$ É curioso que seja $\sigma v \lambda \lambda \alpha \mu \beta a ́ v \in \iota \nu$ "apreender, captar” o verbo usado para a aprendizagem de uma língua, o que põe em relevo o seu carácter essencialmente sonoro e auditivo. 
fala de uma mulher com a que, sujeita à fantasia, fala de uma pomba, Heródoto recorre ainda a um argumento linguístico (2. 57. 1-2): "Julgo que às mulheres foi dado o nome de "pombas" pela razão seguinte: por serem

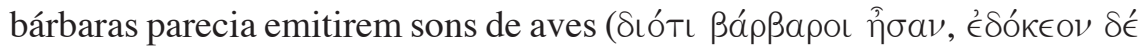

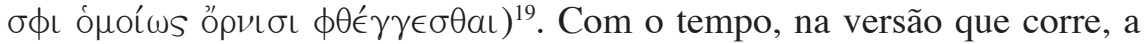
pomba teria ganho voz humana, ou seja, a mulher passou a usar sons que lhes eram compreensíveis; enquanto falava bárbaro ( $\epsilon \beta a \rho \beta a ́ p ı \zeta \epsilon)$, parecialhes que emitia sons de uma ave". Só depois da questão linguística, Heródoto acrescenta outra diferença racial relevante, a cor: na "pomba negra", que a versão de Dodona referia, estava patente uma alusão à fisionomia típica do Egipto. A história é, do ponto de vista linguístico, inspirada numa evidência: a de que, em tempos muito antigos, a incomunicabilidade era total entre diferentes línguas, que obedeciam a uma dicotomia radical entre Gregos e Bárbaros, estes últimos entendidos como uma mescla indistinta e global. Em torno desta realidade, criaram-se ficções, que se tornaram etiológicas e populares. Estávamos, é evidente, ainda longe do séc. V a. C. No entanto, mesmo quando o grande conflito entre a Grécia e o oriente trouxe ao conhecimento mútuo uma outra nitidez, Heródoto podia ainda recorrer a uma metáfora animal, seguindo uma velha tendência, para aparentar a língua incompreensível de uma tribo etíope, remota e incivilizada, "aos gritos agudos dos morcegos" (4. 183. 4) ${ }^{20}$.

No entanto, o séc. V a. C. trouxe à questão das diferenças linguísticas um significado novo e uma perspectiva mais correcta. O conteúdo da palavra "bárbaro" diversificou-se, em função da variedade que ocultava. Foi então possível aos Gregos perceber a diversidade de raças, origens, costumes e línguas dos povos que se distribuíam pelo território da Europa, Ásia e África, e quase intuitivamente entender-lhes as razões de diferença ou de proximidade.

A campanha que um grupo de exploradores líbios, da tribo dos Nasamones, empreendeu pelo território então desconhecido do Sahara ocidental, e que os pôs em contacto com os pigmeus, é ainda exemplo daquela incomunicabilidade radical que foi de regra antes que as barreiras

${ }^{19}$ Outras ocorrências (cf. A. Ag. 1050-1051; Ar. Ra. 681 sq.) provam como, em grego, "piar como uma ave" se aplica a uma linguagem incompreensível. Cf. Taillardat 1965: 299-300.

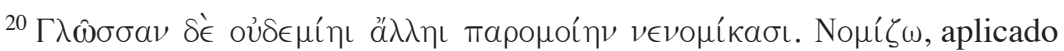
ao uso linguístico, faz da língua um traço civilizacional. 
entre povos tivessem ruído. Não só os pigmeus receberam com inimizade os invasores desconhecidos e os capturaram, como foi impossível qualquer comunicação entre as duas partes (2.32. 6): "Nem os Nasamones entendiam $(\gamma \iota \nu \omega ́ \sigma \kappa \in \iota \nu)$ uma palavra que fosse da língua deles, nem os que os levavam da dos Nasamones". A distância geográfica resulta, portanto, num factor decisivo para a verificação de diferenças profundas, dos costumes em geral e do que respeita à língua em particular. Pode mesmo sobrepor-se à raça e estabelecer, dentro de grupos afins, particularidades significativas. É o caso das fracturas registadas entre os Citas em função da extensão gigantesca do seu território. Assim, à medida que se progride das regiões mais acessíveis, da perspectiva de um grego, para as franjas mais remotas, as diferenças vão-se acentuando. Nos confins da Cítia, há povos que, apesar de se vestirem ao estilo cita, têm fisionomias surpreendentes, hábitos alimentares

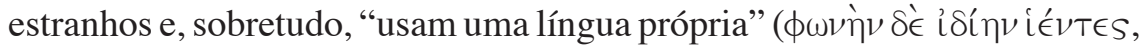
4. 23. 2); outro grupo cita, os Andrófagos, usa trajos do mesmo tipo, mas é de uma selvajaria radical, tem hábitos distintos, e também "uma língua

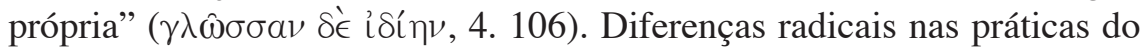
quotidiano, como o sedentarismo face ao nomadismo, justificam a preservação de diferentes códigos, como se verificou ser o caso entre os Indus (3. 98. 3). O mesmo sucede com a reacção de um povo, os Eritreus, que se vê transplantado do seu território para outro, onde tendeu a preservar a

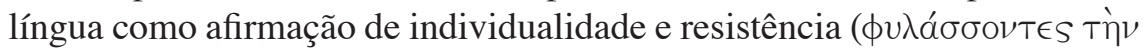

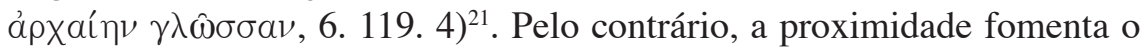
convívio e a fusão linguística; mesmo quando todos os outros costumes resistem, no desejo intuitivo de preservação de uma identidade, a língua tende ao ajustamento ditado pela própria necessidade. Ao avaliar os vários povos da Ásia Menor e ao inventariar-lhes as particularidades, Heródoto sublinha que, por exemplo, Cáunios e Cários que, na sua opinião, são de raças distintas - os primeiros autóctones do continente, os Cários talvez provenientes das ilhas, apesar de eles mesmos defenderem o contrário -, porque em contacto, passaram a falar a mesma língua (1. 172. 1), ainda que mantivessem diferentes costumes. Neste caso, a comunidade linguística parece ocultar uma real diferença de raça, de que, no entanto, há outros sinais evidentes. É o caso da partilha que os Cários, defendendo a sua

${ }^{21}$ Nenci, G. (1998), Erodoto, Le Storie. VI. La bataglia di Maratona. Milano:

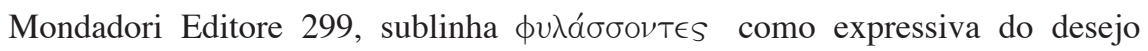
consciente de defender a identidade linguística. 
autoctonia, fazem, com Mísios e Lídios, de um mesmo santuário - de Zeus cário em Mílasos -, enquanto os Cários, apesar de partilharem com eles a língua, não serem aceites na mesma comunidade religiosa.

$\mathrm{Na}$ deslocação de povos, com inevitáveis implicações linguísticas ${ }^{22}$, podem estar envolvidas causas diversas. Consideremos, em primeiro lugar, os objectivos comerciais, que obrigam a múltiplos contactos ou mesmo a uma erradicação definitiva. Exemplificativo é o caso, entre a comunidade cita, dos Gelonos (4. 108. 2), que começaram por constituir um grupo de emigrantes gregos ${ }^{23}$; quando, porém, decidiram abandonar a zona dos "empórios", que antes ocupavam, para se transferirem para uma região vizinha dos Budinos, que eram Citas, passaram a usar uma língua mista (4. 109). Por outro lado, as campanhas militares motivaram também, como o próprio conflito entre Persas e Gregos testemunha, cruzamentos culturais e linguísticos. Assim Heródoto assinala uma, à primeira vista, estranha proximidade entre o egípcio e o colco (2. 102-104), que, apesar da distância a separá-los, se assemelham em costumes e língua. A razão desta afinidade provém de uma campanha levada a cabo na Ásia pelo faraó Sesostris, de consequências duradoiras, por ter permitido a fixação de alguns elementos do exército egípcio na região.

Particularmente interessante é a reflexão que Heródoto dedica às Amazonas e à sua progressiva fusão com os Citas. A partir de uma explicação etimológica (das muitas que existem em Heródoto, como adiante veremos), caracteriza-as pela natureza misândrina que constituía o seu traço principal (4. 110. 1): no nome que lhes era dado pelos Citas, de Eorpata, se aglutinava eor, que significa "homem", e pata, "matar" ${ }^{24}$, numa

${ }^{22}$ Cf. o exemplo dos Amónios, no Egipto, que, por serem colonos dos Egípcios e dos Etíopes, falavam uma língua mista (2. 42. 4). Também Tucídides 4. 109. 4 fala de "bárbaros bilingues".

23 Trata-se dos Gregos que habitavam as costas do mar Negro, então designado por Ponto Euxino, ou "hospitaleiro", dado o número de cidades gregas aí estabelecidas.

${ }^{24}$ É muito discutido o sentido da palavra e a etimologia proposta por Heródoto. Se eor parece ser, de facto, "homem", pata será talvez "dono, senhor"; logo, em sentido global, "dominadoras de homens". Cf. Corcella, A., Medaglia, S. M., Fraschetti, A. (1993), Erodoto, Le Storie. IV. La Scizia e la Libia. Milano: Mondadori Editore 320. Chamberlain, D. (1999), "On atomics onomastic and metarrhythmic translations in Herodotus", Arethusa 32. 3: 273-274, salienta a 


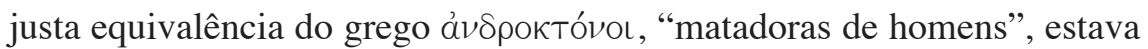
patente essa característica. E logo lhes estabelece a origem, na Capadócia, junto ao rio Termodonte, e a emigração a que a derrota militar sobre elas alcançada pelos Gregos as forçou. É portanto como uma presença estranha que elas iniciam razias devastadoras pelo território cita (4. 110. 2). O resultado foi um primeiro confronto baseado na estranheza, na violência e na incomunicabilidade (4. 111. 1): "Os Citas não compreendiam nada do que se passava; nem conheciam aquela língua, nem os trajos, nem o povo"

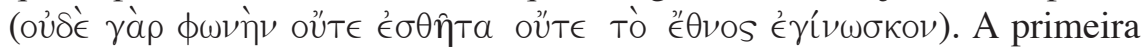
constatação concreta que os Citas obtiveram deste inimigo é que se tratava de mulheres, observados os cadáveres que jaziam após os confrontos. E porque desejavam ter filhos com elas, iniciaram uma estratégia de aproximação. Como "embaixadores" para os primeiros contactos serviramse de um grupo de jovens, que deveriam imitar a atitude das Amazonas, sem nunca as hostilizar. Assim se estabeleceu um primeiro acampamento cita próximo do das estranhas mulheres. Sem que Heródoto o diga explicitamente, nesta ideia de que os jovens citas deveriam "fazer o mesmo que elas faziam", está implícita uma noção de "imitação gestual", que é a primeira arma de contacto a preceder a linguagem (4. 111. 2). Do que foi, a princípio, um código de sinais colectivo se chegou a uma primeira abordagem pessoal, que se baseou no que de mais espontâneo a natureza animal estimula, a evacuação de dejectos e o sexo; eis o que, antes de mais, os Citas e as Amazonas partilharam. Veio então a necessidade de compreensão e aí, à falta de palavras, funcionou a linguagem gestual (4. 113. 2): "Como

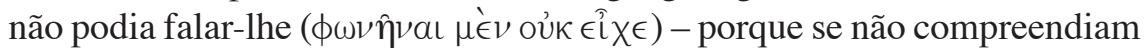
um ao outro -, fez-lhe entender por gestos ( voltasse no dia seguinte ao mesmo lugar e trouxesse um companheiro;

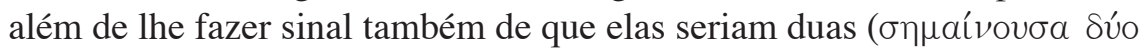
$\gamma \in \nu \in ́ \sigma \theta a \mathrm{l}$ ), porque ela traria também uma companheira". Foi este o primeiro passo para a fusão dos dois acampamentos e dos dois povos. Estabelecida a vida em comum, Heródoto sublinha as dificuldades que então a aprendizagem da língua representou (4. 114. 1): "Os homens não

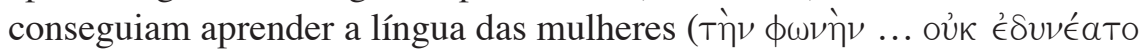

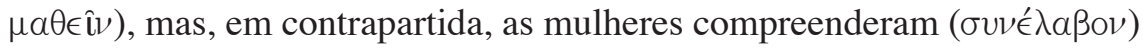

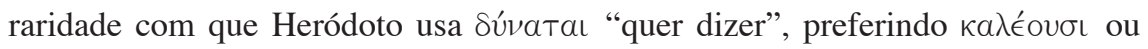

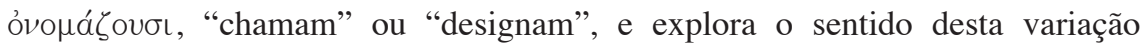
vocabular. 
a dos homens". Só a partir do momento em que puderam "falar", os membros da nova comunidade estruturaram uma verdadeira vida colectiva, pela harmonização, consciente e voluntária, de práticas e costumes. Desta origem resultou, com o curso do tempo, uma forma individualizada entre os Saurómatas, que dela provinham, em hábitos e em língua; diz Heródoto

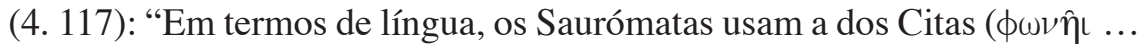

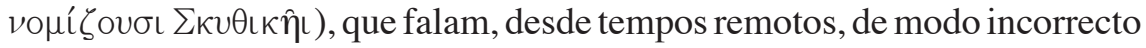

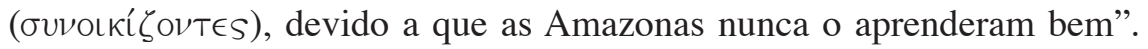
Esta é, sem dúvida, a experiência de aprendizagem de uma língua mais bem hierarquizada por Heródoto, desde a fase gestual até uma capacidade fluente de conversação, sem que se apaguem as marcas específicas de cada um dos códigos originais. Curioso é o pormenor de que pareça ser atribuída às gerações mais jovens e às mulheres uma maior facilidade nessa aquisição.

Do episódio das Amazonas sobressai também um processo, o da aquisição voluntária de uma outra língua, essencial na resolução das questões da rotina quotidiana ou mesmo daquelas excepcionais em que está em risco a própria vida. Exemplar é o caso de Histieu de Mileto, que escapou ao golpe mortal de um perseguidor persa, por ter sido capaz de se

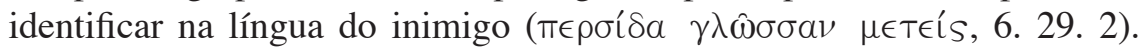
Significativa, num contexto de guerra, é a conversa havida, durante um banquete em Tebas, entre um persa e um tebano acomodados no mesmo leito, graças à competência do persa em falar grego ( ${ }^{2} \lambda \lambda \alpha \alpha^{\delta} \alpha \quad \gamma \lambda \hat{\omega} \sigma \sigma \alpha \nu$ iє́vTa, 9. 16. 2); representando interesses contraditórios, a conversa funcionou como uma espécie de profecia sobre o desfecho próximo das hostilidades. Na época clássica, este objectivo parece ter evoluído como uma tendência natural, dado que, com a demolição de barreiras entre povos, o plurilinguismo se revelou uma competência desejável.

Esse multilinguismo advém, por vezes, da própria circunstância de os progenitores pertencerem a grupos étnicos diferentes, o que se terá tornado uma possibilidade cada vez mais acessível. Nestes casos, Heródoto atribui às mães o principal papel ${ }^{25}$. Já o vimos latente no exemplo das Amazonas que, elas mesmas falantes imperfeitas da língua dos maridos, marcaram para o futuro as características específicas da língua dos Saurómatas (vide supra). Outro tanto se passou no caso de Ciles, o filho do rei cita Ariápites,

${ }^{25}$ Cf. Dewald, C. (1981), "Women and culture in Herodotus" Histories", in Foley, H. P. (ed.), Reflections of women in Antiquity. New York: 91-125. 
cuja mãe, uma grega da Ístria, lhe ensinou - no que parece uma preocupação muito consciente e direccionada para objectivos concretos - "a ler e a

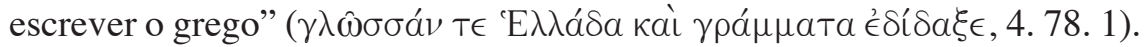
$\mathrm{Ou}$ ainda com as mulheres atenienses, capturadas e feitas concubinas em Lemnos, que aos numerosos filhos que vieram a ter se preocuparam em

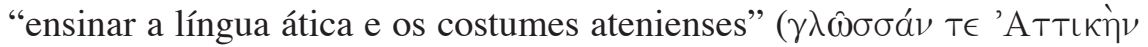

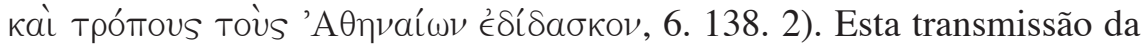
língua por parte da mãe resulta, por um lado, da maior intervenção materna na educação das crianças; mas é também portadora da intenção de defender as raízes que a mulher, transplantada da sua pátria, não quer perder, ou que pretende que funcionem como defesa do seu estatuto na terra que a recebeu. Logo o código linguístico aparece relacionado com a identidade, mas também com hierarquização e prestígio social.

Com a evolução que o mundo global então seguiu, o plurilinguismo tornou-se uma necessidade, para fazer frente aos contactos que o quotidiano exigia. Se não se pode ainda falar de intérpretes profissionais, como aqueles que prestam um serviço de tradução e por isso são remunerados, é, no entanto, evidente que, junto das cortes poderosas da Pérsia e do Egipto, com tendência para uma intervenção cada vez mais ampla, havia elementos competentes na tradução, sobretudo daquelas línguas, como o grego, que facultavam contactos assíduos e fundamentais. Ciro, por exemplo, "tinha na sua corte gregos", a quem consultava sobre a realidade do seu país e de quem se podia servir como intérpretes (1. 153. 1); para dialogar com Creso, o rei da Lídia que tinha condenado à morte na pira, Ciro serviu-se também de intérpretes (1. 26. 4); do mesmo modo que, junto de Dario, vivia o grego Democedes que, além de médico da corte, podia prestar o mesmo tipo de informações e de serviços (3. 129 sqq.). A cena em que Dario confronta Gregos e Indus sobre o valor relativo dos respectivos costumes funerários (3. 38. 3-4), tem por participantes inevitáveis os "intérpretes" - "era através

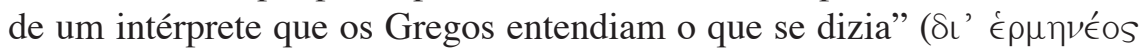
$\mu \alpha \nu \theta \alpha \nu o ́ \nu \tau \omega \nu$ та $\lambda \epsilon \gamma o ́ \mu \in \nu a)$. Do mesmo modo que o acesso de Silosonte ao rei, no intuito de lhe cobrar um favor de outrora, é filtrado pelos intérpretes, que, na presença de Dario, produzem a tradução das suas pretensões (3. 140. 3). Este é o retrato da sala de audiências da corte persa, onde os tradutores assessoram o monarca. Mas, naturalmente, a diplomacia impunha-se também, nas relações no exterior, processo tanto mais difícil de solucionar quanto mais distante e remoto fosse o alvo a atingir. Assim Cambises, ao planear uma campanha contra a Etiópia, teve de procurar em 
Elefantina, no Egipto, "alguns Ictiófagos ${ }^{26}$ que conhecessem a língua etíope"

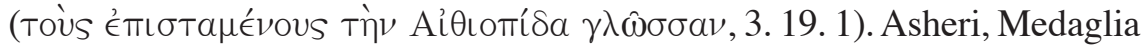
e Fraschetti (ibidem) admitem ainda que estes Ictiófagos bilingues pertencessem à classe dos "intérpretes", pela sua competência rara. Também os Citas possuíam classes de intérpretes (4. 24), com uma versatilidade exigida pela própria dimensão e variedade étnica e linguística que lhes era própria. Assim, na zona intensamente comercial que circundava o mar Negro, os Citas podiam servir-se de "sete intérpretes e de sete línguas" (4. 24).

Naturalmente que esta situação tinha o seu reverso; também os Gregos podiam, se quisessem, obter informações precisas da realidade egípcia através dos seus compatriotas de há muito lá residentes; trata-se até, precisa Heródoto a propósito dos Iónios e dos Cários no delta do Nilo, de antigos mercenários aceites e instalados no Egipto por Psamético I, "dos primeiros

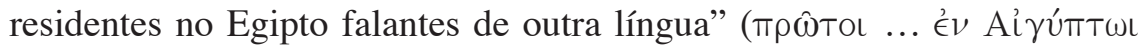
ả $\lambda \lambda$ ó $\lambda \lambda \omega \sigma \sigma o \iota ~ \kappa a \theta o \iota k i ́ \sigma \theta \eta \sigma \alpha \nu, 2.154 .5)^{27}$. Aliás o exemplo da política de Psamético para promover uma difícil harmonização entre Egípcios e Gregos no seu exército ${ }^{28}$, inclui a questão linguística, que pareceu ao soberano fundamental para uma verdadeira fusão. Por isso, o faraó confiou à comunidade cária e iónia, que os antigos mercenários agora constituíam, jovens egípcios, para que lhes ensinassem o grego (2. 154. 2). Foi notório o resultado dessa medida, como Heródoto salienta: "É desses jovens que aprenderam o grego que descendem os intérpretes que hoje em dia existem no Egipto", uma das sete "classes" do país ${ }^{29}$. Expediente semelhante, de

${ }^{26}$ Em Asheri, D., Medaglia, S. M., Fraschetti, A. (1990), Erodoto, Le Storie. III. La Persia. Milano: Mondadori Editore 236, os Ictiófagos são assim definidos: "Em grego, o epíteto de Ictiófago indica, também em muitos autores posteriores a Heródoto, povos costeiros primitivos, semilendários e utópicos, que viviam nos extremos do mundo civilizado, sobretudo no golfo Pérsico e no mar Vermelho, na área do Cáspio e na costa ocidental da Índia”.

${ }^{27}$ Sobre a presença de Gregos e Cários em Mênfis, vide Lloyd, Fraschetti ${ }^{3}$ 1996: 371; How and Wells 244. Provavelmente Heródoto situa este processo a partir do séc. VII a. C.

${ }^{28}$ Esta tensão provinha de uma política adoptada por Psamético de contratar mercenários estrangeiros, perante a atitude de distanciamento, em relação ao rei, que a classe militar egípcia tinha assumido. A prerrogativa de que os Gregos gozavam no exército egípcio, como tropas de elite, deu origem a inúmeros conflitos.

${ }^{29}$ A sexta das sete que Heródoto enumera em 2. 164. 1. Cf. How and Wells 1991:248-249. 
deslocar um grupo de jovens para outra comunidade com o intuito específico de os fazer aprender uma outra língua, foi assumido por Ciaxares, então rei dos Medos, face aos Citas, com quem se encontrava em boas relações (1. 73. 3).

O que foi sem dúvida, no início, um projecto de natureza política para facilitar contactos ou promover fusões étnicas - foi ganhando, com o tempo, o perfil de uma prática generalizada. Dario, por exemplo, perante a variedade linguística que coexistia dentro do seu império, promoveu o bilinguismo como uma prática corrente na divulgação de avisos públicos (4. 87. 1): "Nas margens do Bósforo, mandou erguer duas estelas em mármore branco; numa em caracteres assírios e na outra em caracteres gregos, estavam registados todos os povos sob seu comando". Proporcionava deste modo uma leitura, numa língua da região, o grego, acessível a quem não conhecia o persa e a respectiva escrita cuneiforme. Desta vulgaridade com que a tradução passou a funcionar dentro de impérios cada vez mais multi-raciais beneficiou o próprio historiador, nas suas "investigações". Lembra Heródoto, por exemplo, que, aquando da visita que fez à pirâmide de Quéops, se serviu do apoio de um intérprete que lhe decifrou, dos caracteres egípcios nela gravados, pormenores sobre os gastos envolvidos na mão de obra $(2.125 .6)^{30}$.

Em contrapartida, o mundo grego sofria uma evolução paralela. É disso exemplo o episódio ocorrido no templo de Apolo Ptoo, junto ao lago Copaís, na Beócia, onde um homem de nome Mis, às ordens de Mardónio, foi fazer uma consulta (8. 135. 1-3). Apesar de se ter feito acompanhar de três cidadãos locais, que pudessem registar as palavras, proferidas em grego, do oráculo, eis que "o sacerdote se exprimiu numa língua bárbara" ( $\beta a \rho \beta a ́ \rho \omega \iota ~ \gamma \lambda \omega ́ \sigma \sigma \eta \iota ~ \chi \rho \hat{\nu} \nu$ ). A surpresa dos Gregos é, afinal, resolvida pelo estrangeiro que, sem necessidade de intérprete, se encarregou de registar por escrito o que o sacerdote dizia, "informando que se exprimia em cário"

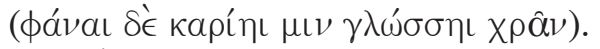

É em função desta nova ordem estabelecida nas relações humanas que o próprio Heródoto inclui, com frequência, na sua narrativa exercícios

${ }^{30} \mathrm{O}$ conteúdo, muito controverso, da inscrição - "sobre a pirâmide está indicado, em caracteres egípcios, o que se gastou, para os trabalhadores, em rabanetes, cebolas e alhos" -, além de ter desencadeado, entre os comentadores de Heródoto, inúmeras hipóteses de interpretação, pôs também em causa a própria qualidade do tradutor (cf. 2. 141. 6); vide Lloyd, Fraschetti ${ }^{3} 1996: 346$. 
de tradução ou explicações etimológicas ${ }^{31}$. Não se trata propriamente de um testemunho de plurilinguismo, mas da sensibilidade de um homem viajado, atento ao contraste de culturas, que, a costumes ou práticas distintos, faz corresponder a nomenclatura equivalente em grego. Há campos semânticos privilegiados, além da generalidade dos antropónimos, etnónimos e topónimos ou de aspectos culturais dispersos: a religião, a política, as medidas, os produtos alimentares, a fauna e a flora.

Sobre os nomes próprios dos Persas, Heródoto regista duas particularidades: a de que são falantes, ou seja, significam algo como uma qualidade física ou psicológica, e a de que, foneticamente, tendem para um mesmo som final, uma sibilante, explica o historiador, "a que os Dórios chamam san e os Iónios sigma" (1. 139). Mas vai mais longe a informação de alguém que se apresenta como um pesquisador interessado nestas matérias. Se a tal homofonia escapa, pela vulgaridade, aos falantes de persa, é visível ao ouvido de um estrangeiro e até incentivadora de uma pesquisa. Feita essa averiguação "estatística", pode verificar-se que a percentagem de nomes nestas circunstâncias é de 100\% ${ }^{32}$. Em 6. 98. 3, Heródoto integra ainda um exercício de análise de nomes régios tradicionais na Pérsia, com o seu correspondente grego - Dario "belicoso", Xerxes "guerreiro", Arta-

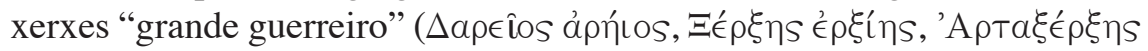

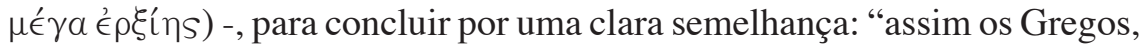
na sua língua, poderiam designar estes monarcas com rigor" ${ }^{33}$. Comentários equivalentes são feitos sobre antropónimos no caso de outros povos; a aplicação matriarcal em vigor na Lícia, onde é o nome da mãe que se herda e não o do pai (1. 173. 4-5); ou a equivalência do nome de um rei do Egipto, que, diz Heródoto, "em grego seria Proteu" (2. 112. 1); assim tentava a helenização da palavra egípcia Pir-o-iti, que significa "soberano"

${ }^{31}$ Tem sido muito discutida e desvalorizada a competência de Heródoto em matéria linguística; cf. Chamberlain 1999: 265.

32 Os comentadores modernos assinalam o exagero desta afirmação. A terminação -s só é verdadeira para os nomes masculinos e, mesmo nestes, só em formas helenizadas. Quanto ao sentido, há também outras fontes de inspiração, como os nomes dos deuses, por exemplo. Cf. How and Wells 1991: 117.

${ }^{33}$ É curiosa a doutrina de Nenci 1994: 260 a propósito deste passo: por um lado, defende-lhe a autenticidade com base na tendência de Heródoto para as etimologias; mas não deixa de dar eco da crítica moderna que as considera todas erradas. Cf. ibidem a informação bibliográfica sobre a matéria; e ainda Chamberlain 1999: 267-272. 
e que constitui um título dado ao faraó, aproximando-a de um vocábulo grego familiar, o que o próprio sentido facilitava.

Os etnónimos colocam também algumas questões sugestivas. Vejamos o caso dos Citas e dos diferentes clãs cobertos por essa designação. Afirma Heródoto $^{34}$, referindo-se à designação colectiva que lhes cabe (4. 6. 2): "A designação comum a todos seria Escólotos. Cita foi o nome que lhes deram os Gregos, a partir do nome do seu rei”. Independentemente da controvérsia gerada por esta afirmação, é interessante registar como, na Grécia, o acolhimento de um mundo desconhecido se foi importando e obrigando à criação de uma nomenclatura nova, que obedece a critérios próprios e acessíveis ao entendimento helénico, como seja o de relacionar o nome de um povo com o do seu herói epónimo. Dentro dos grupos étnicos em que os Citas se repartem, Heródoto refere-se em particular a algumas designações, fornecendo ao seu leitor etimologias ou traduções para o grego; os Arimaspos, assim designados na Grécia, usam um nome "cita, pois

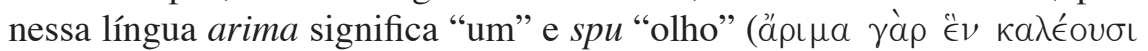

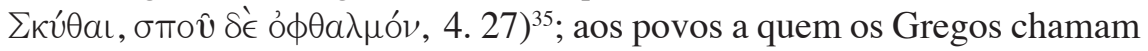

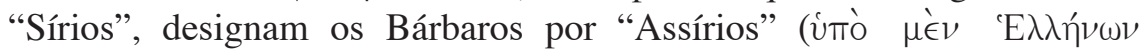

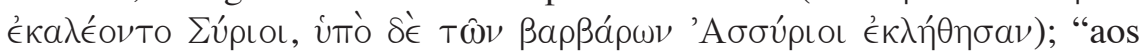
Citas Amírgios chamava-se Sacas, porque Sacas é o nome que os Persas

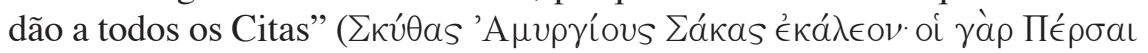

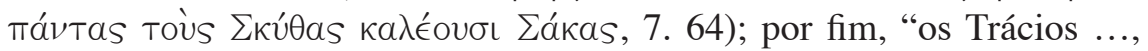
depois de passarem à Ásia, tomaram o nome de Bitínios; antes, de acordo com o que os próprios afirmam, eram chamados Estrimónios, por habitarem

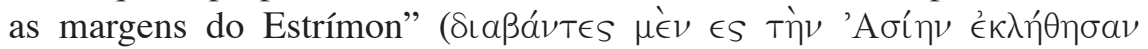

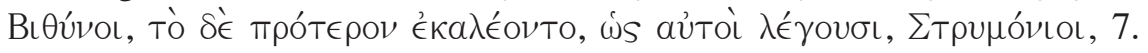
75); do mesmo modo que "os Frígios - ao que dizem os Macedónios - se chamavam Brigos, durante todo o tempo em que habitaram a Europa, junto

${ }^{34}$ Afirmação, de resto, muito polémica. Corcella, Medaglia, Fraschetti 1993: 234, lembram que entre Escólotos, com o elemento inicial sku-, "que faz mover",

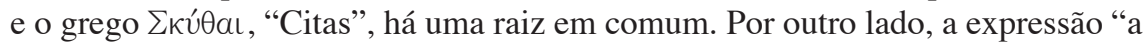
partir do nome do seu rei" cria dificuldades.

${ }^{35}$ Mais uma vez a etimologia sugerida suscita dúvidas; cf. Corcella, Medaglia, Fraschetti 1993: 256. Eustátio, A Dioniso 31, dá a leitura de ari como equivalente a "um" e maspos a "olho". Mas outras sugestões são também propostas com base em raízes irânicas: assim aspa "cavalo" e arima "selvagem" faria dos Arimaspos "o povo dos cavalos selvagens". Sobre o nome aplicado às Amazonas, vide supra nota 24. 
aos Macedónios; ao passarem à Ásia, ao mesmo tempo que mudaram de

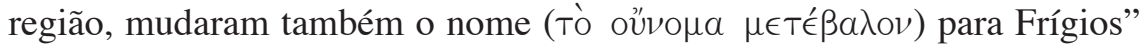
(7.73.1). Naturalmente a ideia de relacionar um povo com a área geográfica correspondente justifica que Heródoto inclua também nos seus interesses os topónimos. Assim, pode parecer-lhe claro que uma designação geográfica esteja deslocada no contexto em que se encontra e se explique pela implantação no local de um povo estranho; é o caso da justificação dada para o nome, nitidamente grego, da cidade de Arcandrópolis, no Egipto (2. 98. 2): "A outra cidade, julgo eu, foi buscar o nome ao genro de Dânao, Arcandro $^{36}$. (...) De facto, dá-se-lhe o nome de Arcandrópolis (...), nome que não é egípcio"; para a cidade a que os Egípcios chamam Oásis ${ }^{37}$, na direcção ocidental a caminho da Líbia, ocupada por Sâmios, a designação

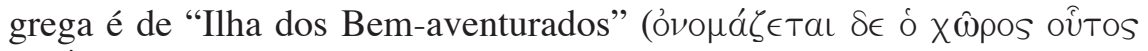

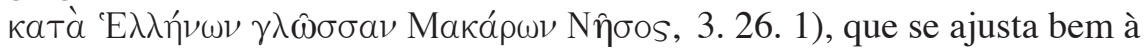
reacção de um grego perante a realidade estranha de um oásis. Observações paralelas são as que merecem os rios e sugestiva a que envolve o nome do Erídano ${ }^{38}$ " "nos confins ocidentais da Europa" (3. 115. 1); Heródoto duvida da existência de um rio com este nome - "não me parece aceitável que os Bárbaros chamem Erídano a um rio que desemboca no mar, na direcção do Bóreas" -, nem de um mar a ocidente da Europa; mas sobretudo "o próprio nome de Erídano indica que se trata de uma palavra grega e não bárbara, inventada por um qualquer poeta" (3. 115. 2). A marca helénica parece resultar da forma épica $\hat{\jmath} \rho$, “cedo, pela manhã”, comum na formação de antropónimos (Erígono, Erictónio, por exemplo). A par dos rios, incluemse as nascentes, como a designada em cita por Exampeu, que, em grego, equivale a "caminhos sagrados" (4. 52.3).

Em termos geográficos, merece ainda atenção a explicação que Heródoto dá para os nomes dos continentes então conhecidos, Líbia, Ásia

${ }^{36}$ Arcandro era um herói aqueu, que aparece ligado na tradição ao mito de Dânao e das suas filhas; esta circunstância relaciona-o facilmente com o Egipto.

${ }^{37}$ Segundo Estrabão 2. 5. 33, 17. 1. 5, "oásis" tornou-se um nome comum para todos os oásis depois de ter sido o nome concreto desta região no deserto líbico. Tratava-se de centros de apoio para as caravanas, apetrechados de zonas residenciais, templos e bases militares de protecção.

38 Asheri, Medaglia. Fraschetti 1990: 331-332 sistematizam a aplicação do nome de Erídano na literatura grega antiga e revelam a insegurança da sua aplicação (ao Ródano, na Ibéria, a um curso da zona adriática, germânica, ou seja, ao Pó). 
e Europa (4. 45. 2-5). É óbvio, para o historiador de Halicarnasso, que a delimitação de fronteiras entre os continentes e as respectivas designações remontam a uma época remota e a uma autoria impossível de identificar ${ }^{39}$. Mas há uma origem que reconhece como incontornável: trata-se de nomes de mulheres ${ }^{40}$. Assim Líbia, de acordo com a opinião generalizada entre os Gregos, ascende ao nome de Líbia, uma mulher natural da região, que o mito identificava como filha de Io e mãe de Agenor e Belo, heróis da Fenícia $^{41}$. Enquanto Ásia levanta ao próprio Heródoto maiores dificuldades: ou ascendia "à mulher de Prometeu", ou, de acordo com a reclamação dos Lídios, "Ásia teria sido assim chamada de Ásies, filho de Cótis e neto de Manes" ${ }^{42}$, de onde recebeu nome também "a tribo Asíade, em Sardes". Por fim, o nome de Europa tem para Heródoto uma origem desconhecida ${ }^{43}$, "a menos que se diga que a designação lhe veio do nome de Europa de Tiro ${ }^{44}$.

${ }^{39}$ Apesar de, em 2. 16. 1, esta tripartição ser atribuída aos Iónios.

40 Sobre a controvérsia suscitada por esta afirmação, vide Lloyd, A. B. (1976), Herodotus. Book II. Commentary 1-98. Leiden: 82-85. É oportuno lembrar ainda o comentário feito a propósito por Rocha Pereira, M. H. (2005), "Europa: os enigmas de um nome", in Fialho, M. C., Silva, M. F., Rocha Pereira, M. H. (eds.), Génese e consolidação da ideia de Europa. Coimbra: Imprensa da Universidade 9: "Pela nossa parte, apenas podemos reconhecer a possibilidade de uma figura, mitológica ou não, dar o nome a um lugar ou mesmo a uma região - conquanto seja mais comum o contrário, a saber, criar-se um aition para explicar a origem de um topónimo, ou mesmo de um corónimo".

${ }^{41}$ Além desta explicação, registada por Heródoto como corrente, há uma outra que faz de Líbia uma das filhas de Oceano, irmã de Ásia e de Europa. Sobre Líbia, cf. Pi. P. 9. 55; A. Supp. 316.

${ }^{42}$ Segundo a tradição documentada por Hes. Th. 359, Ásia era filha de Oceano e Tétis e mãe de Prometeu, Epimeteu e Atlas, o que não coincide com a versão de Heródoto. Quanto a Manes, é o nome do primeiro rei mítico da Lídia (cf. 1. 94. 3 ).

${ }^{43}$ Embora modernamente uma relação com €úpús "largo" tenha alguns defensores (cf. 4. 42. 1, em que Heródoto se refere à largura ímpar da Europa, í

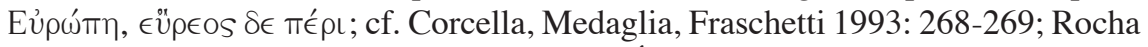
Pereira 2005: 12-14. Do mesmo modo que Ásia poderia provir da palavra hitita para "terra boa".

44 "Europa" ocorre pela primeira vez em Hesíodo, incluída no catálogo das filhas de Tétis e de Oceano (Th. 346-366), uma Europa distinta da princesa fenícia, naturalmente. A primeira aplicação geográfica do nome vem no Hino Homérico a Apolo 250-251, onde simplesmente se refere ao continente grego, por contraste com o Peloponeso e as ilhas. 
Assim a princípio não teria nome, como as restantes partes da terra. Mas parece certo que a tal Europa era oriunda da Ásia e que nunca chegou a esta região a que os Gregos chamam "Europa"; veio apenas da Fenícia para Creta, e de Creta para a Lícia" ${ }^{45}$.

No que a nomes próprios diz respeito, os que se aplicam aos deuses e a circulação que tiveram no lado oriental do Mediterrâneo é motivo de diversas referências em Heródoto. É aos Egípcios que - feita uma investigação sobre o que parecia uma evidência, que se tratava de nomes

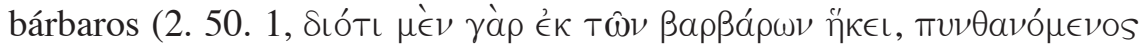

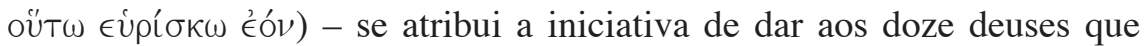
vieram a constituir o panteão grego ${ }^{46}$ nomes expressivos ou "falantes"

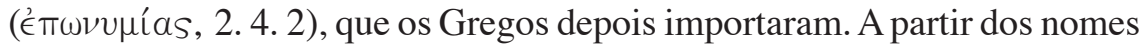
egípcios, foi possível individualizar as divindades, substituindo designações e atributos específicos ao que antes era uma nomenclatura atípica ${ }^{47}$ de $\theta \in$ oús, com tradição pelásgica (2. 52. 1-3), que Heródoto familiariza com

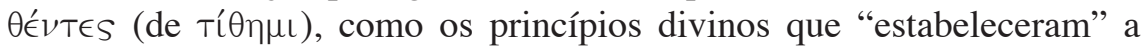
ordem no universo. Em matéria tão susceptível como a que envolve o culto, diz o historiador que houve necessidade de aprovação divina para se proceder à importação. Por isso, foi só com o aval do oráculo de Dodona que os Pelasgos aceitaram a nomenclatura egípcia para o panteão divino e, depois deles, também os Gregos, a partir de Homero e Hesíodo; o facto de os Pelasgos serem tradicionalmente considerados como os habitantes autóctones pré-dóricos da Hélade revela a antiguidade desta substituição. Os contactos a que o séc. $\mathrm{V}$ a. $\mathrm{C}$. assistiu com povos de todos os continentes implica por parte de Heródoto, ao considerar os vários cultos, que produza "traduções" ou equivalentes entre deuses e as respectivas designações.

${ }^{45}$ Europa, filha do rei de Tiro, foi, de acordo com o mito, raptada por Zeus sob forma de um touro; em Creta, onde o amante divino a depôs, deu à luz Sarpédon, Minos e Radamante (cf. 1. 173. 2).

${ }^{46}$ Cf. 2. 50. 2-3, 2. 52. 2, onde Heródoto exclui os nomes de deuses que lhe parecem não pertencer ao "conjunto egípcio". São de origem pelásgica os Dioscuros, Hera, Héstia, Témis, as Graças e as Nereides, e líbia Posídon (o que é um erro, dada a origem indoeuropeia incontroversa do deus do mar, apesar de ter na Líbia um culto muito enraizado; cf. Pi. P. 4. 33, 45).

${ }^{47}$ Não se trata propriamente de designar os deuses gregos com nomes egípcios, porque o próprio Heródoto assinala paralelos entre designações diferentes, como Zeus e Ámon (2. 42. 5). A novidade está na individualização de cada deus e na fixação dos seus atributos, uma prática egípcia. 
Assim, por ex., para Afrodite Urânia, as Histórias dão-nos a versão em assírio, Milita, em árabe, Alitat, e em persa, $\operatorname{Mitra}^{48}$ (1. 131. 3; cf. 1. 199. 3). Em 3. 8. 3, Heródoto lembra que pelos Árabes "Dioniso é chamado Orotalt e Urânia Alitat". Uma observação interessante é a de que parece haver uma assonância entre os nomes persas e aqueles com que os Gregos designavam os seus festivais (1. 148. 2); a propósito dos chamados Panionia, sublinha Heródoto: "Não são só as festas dos Iónios que obedecem a este tipo de expressão, mas o mesmo se passa com todas as festas gregas que também terminam com a mesma letra, como os nomes persas"49. Se olharmos do quadrante egípcio, algumas correspondências são também referidas, como a de "Ápis, em grego Épafos" (2. 153, 3. 28. 2), ou seja, do boi sagrado de Mênfis com o filho de Zeus e Io (cf. A. Pr. 850-851); por fim, quanto aos Citas (4. 59. 2): “em cita, Héstia chama-se Tabiti; Zeus, Papeu, nome que acho perfeitamente adequado; a Terra, Api; Apolo, Getósiro; Afrodite Urânia, Argímpasa; Posídon, Tagimásadas" ${ }^{50}$.

No plano institucional, merecem a Heródoto atenção particular algumas designações relativas a cargos ou circunscrições administrativas. Estão neste caso as províncias com um governo regional a que os Persas chamam "satrapias" $(1.192 .2,3.89 .1)^{51}$, ou a designação dos "benfeitores" 52 do rei, que, em persa, se chamam orosangas (8. 85. 3). Outro exemplo é o dos "desertores", um grupo egípcio assim designado por um acto de traição num combate frente aos Etíopes (2. 30. 1), o vizinho do sul do país. O

${ }^{48}$ A referência a Mitra, em vez de Anaita, é um erro grosseiro, de Heródoto ou de um copista, porque se trata de uma divindade masculina, deus irânico da luz solar. De facto, a relação que se propõe é entre Afrodite e Milita na Babilónia, e Astarte na Fenícia. Ishtar, mãe dos deuses, divindade ao mesmo tempo guerreira e protectora da geração, circulou da Assíria para a Fenícia e daí para Chipre. É a consciência de que se trata de uma divindade estrangeira que justifica o epíteto de Cípris que recebeu na Grécia. Milita é, também, em assírio, "a senhora"; Alitat (Al Itat), em árabe, "a deusa”.

${ }^{49}$ Ou seja, em $-a$, representativo de plural neutro. Sobre a simetria na terminação dos nomes persas, cf. 1. 139 (vide supra).

${ }^{50}$ Sobre a interpretação destas correspondências, vide Corcella, Medaglia, Fraschetti 1993: 279-282.

${ }^{51}$ Para "satrapia", que sente como um estrangeirismo, Heródoto usa o grego vouós. Cf. How and Wells 1991: 281, sobre a importância da palavra persa nos vários autores gregos.

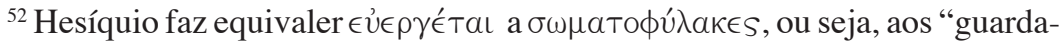
costas" reais. 
nome destes desertores é $A s m a c h^{53}$, palavra que, traduzida para grego, equivale a "os que estão à esquerda do rei", ou seja, detentores de um prestígio menor. $\mathrm{O}$ nome dado ao rei pelos Líbios merece a Heródoto uma explicação minuciosa e uma tradução cuidada (4. 155. 1-2), surgida a propósito da colonização de Cirene por Gregos de Tera. Segundo a versão dos Tereus e Cireneus, o fundador grego de Cirene usaria o nome de Bato, como uma alcunha alusiva à sua linguagem entaramelada; logo a palavra seria uma espécie de onomatopeia de origem grega. Heródoto, porém, inverte esta hipótese ${ }^{54}$, quando diz: "Mas, em minha opinião, <esse fundador $>$ teria outro nome, e só quando foi para a Líbia passou a chamarse Bato - nome que ele mesmo inventou, a partir do oráculo proferido em Delfos (...): os Líbios chamam ao rei "Bato", razão por que a Pítia - penso eu -, ao emitir o oráculo, o designou com esta palavra, na língua líbia, por saber que ele viria a ser rei dessa região. Assim que se tornou homem, deslocou-se a Delfos por causa da voz. Às suas perguntas foi esta a resposta da Pítia: "Vieste, Bato, por causa da voz; mas o divino Febo Apolo envia-te a colonizar a Líbia, rica em ovelhas". Era como se lhe dissesse em grego: "Vieste, rei, por causa da voz ..."”. Mais uma vez Heródoto abona o prestígio e o concomitante multilinguismo do oráculo de Delfos ${ }^{55}$.

Do quotidiano, o nosso autor atenta em realidades comezinhas, como as que dizem respeito a medidas. Recorda o artabo (1. 192. 3), "uma medida persa, que leva mais três litros do que o medimno ático"s6; como também as medidas agrárias em vigor no Egipto (2. 6. 2-3): "Os pobres medem a terra em orgias, os remediados em estádios, os grandes proprietários em esquenos ${ }^{57}$. A parasanga ${ }^{58}$ corresponde a 30 estádios; um esqueno,

${ }^{53}$ How and Wells 1991: 175 distinguem a tradição popular de asmach como "esquerda", do verdadeiro sentido da palavra "esquecer" - alusiva à exclusão dos desertores - por haver, em egípcio, uma grande semelhança entre as palavras com estas duas aplicações. A posição "à esquerda do rei” era a que ocupavam, no exército egípcio, enquanto os mercenários gregos alinhavam à direita; cf. Schrader 1992: I-II, 311.

${ }^{54}$ Cf. Pi. P. 5. 87, que chama a Bato Aristóteles.

${ }^{55} \mathrm{Cf}$ supra nota 15.

${ }^{56}$ A popularidade desta palavra no grego permite que Aristófanes a use na formação do nome cómico de Pseudartabas, o olho do rei e seu emissário em Ach. 91-125.

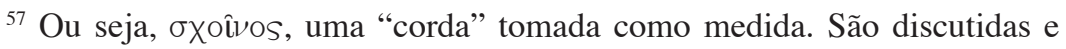
contestadas as medidas dadas por Heródoto.

${ }^{58}$ A parasanga era uma medida de comprimento persa (6. 42. 2). 
que é uma medida egípcia, a 60 estádios"; a que acrescenta, também como medida agrária egípcia, a arura (2. 168. 1).

Os produtos alimentares, com a sua natural particularidade, proporcionam um choque vocabular. Do Egipto recorda-se a especificidade do pão, feito com um cereal diferente "a que uns chamam ólira, outros zeia" (2. 36. 2), conhecido por kyllestis (2. 77. 4). Para o fabrico do pão usam também "aquilo que os Egípcios chamam lótus", de cujas sementes "se faz um pão cozido no forno" (2. 92. 2). Das raízes do rícino extraem um óleo "a que chamam kiki" (2. 94. 1). Do oriente, refere a existência de umas cascas que, ao que se conta, "aves avantajadas transportam para fazer os ninhos, e que nós aprendemos com os Fenícios a chamar cinamomo" (3. 111. 2); à falta de uma palavra grega para exprimir este produto, Heródoto serve-se da original. Mas no caso do "ládano, que os Árabes designam por ládanon" (3. 112; cf. 3. 107. 1), Heródoto assinala que o grego conhece o produto e a palavra, embora a pronuncie com uma tonalidade ligeiramente diferente ${ }^{59}$. Por fim, do persa refere a designação de um óleo como radinace (6. 119.3).

A fauna é também um tema atractivo, sobretudo a africana, que reservava, para um grego, algumas surpresas. Assim o "crocodilo" (2. 68), que Heródoto descreve com minúcia e de que discute o nome (2. 69. 3): "<Os Egípcios> não lhes chamam crocodilos, mas sim champsai. Foram os Iónios a designá-los por crocodilos, pela semelhança que têm com os lagartos que lá existem nos muros". Esta é uma outra forma de importação linguística, que consiste em aplicar, por comparação, a uma realidade estranha uma palavra própria usada para algo similar. Ou ainda, a propósito das três raças do rato líbio, os zegéries, "termo líbio equivalente ao grego bounoi" (4. 192. 3; cf. 4. 199. 1) ${ }^{60}$.

Muitos outros campos semânticos dispersos ${ }^{61}$ completam a policromia de um mundo de sedução e de surpresa para os olhos extasiados de um

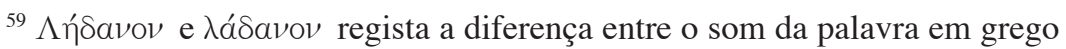
e em árabe.

${ }^{60}$ A palavra líbia equivale a "planalto", de onde talvez a equivalência com Bouvós "colina".

${ }^{61}$ Recordemos exemplos dispersos como, entre os Egípcios: o "canto de Lino", ou Adónis, "nome que varia de povo para povo, apesar de todos concordarem em que se trata do mesmo canto, que os Gregos designam como "de Lino" (...). Em egípcio, Lino chama-se Maneros" (2. 79. 1-2); "as túnicas de linho, com franjas em volta das pernas, a que dão o nome de kalasiris" (2. 81. 1); 
europeu. Mas a toda essa descoberta corresponde um esforço de penetração que só a comunicação pela palavra pode tornar efectivo.

um barco, designado por baris (2. 96. 5); ou ainda um pormenor arquitectónico das pirâmides, os degraus, "a que uns chamam crossai e outros bomides" (2. 125. 1). Saltando para a Ligúria (5. 9. 3): "Os povos que vivem no interior norte de Marselha designam por siginas os vendedores ambulantes, enquanto os Cipriotas dão este nome aos dardos"; pretende assim Heródoto explicar o nome de um povo, os Siginas, tribo remota a norte do Danúbio, como gente dedicada ao comércio e que, segundo Nenci, G. (1994), Erodoto, le Storie. V. La rivolta della Ionia. Milano: Mondadori Editore 166, talvez usassem pontas de lança como moeda de troca, numa tentativa de harmonizar as duas leituras do nome que usam, segundo Heródoto. Dos Persas, "uma espada a que chamam akanikes" (7. 54. 2; cf. 3. 118. 2, 3. 128. 5); "o serviço de correios a cavalo, designado por angareion" (8. 98. 2); ou o dia do aniversário real que, "em persa, se chama tyktá e, em grego, teleion" (9. 110. 2). 